\title{
Renters Rising! Extending the analysis of housing activism in Europe to the UK
}

\section{¡Iniquilinos rebelándose! Ampliando el análisis del activismo de vivienda en Europa al Reino Unido}

\section{Andrew Mathers ${ }^{1}$ \\ University of the West of England (United Kingdom)}

ORCID: https://orcid.org/0000-0002-9046-3441

Recibido: 02-03-2020

Aceptado: 03-06-2020

\begin{abstract}
The material effects of austerity in the United Kingdom (UK) have generated a resurgence of activist initiatives in the field of housing central to which is ACORN that has developed into a federated organisation contesting housing practices and policies at both local and national levels. ACORN is used to expand the examination of housing activism in Europe beyond the cases in Spain and Germany to the UK (Ordonez et al, 2015). This article also utilises the qualitative methodology of a comparative case study and the framework of ideological and social backgrounds, political repertoires and political logics to present and analyse ACORN. While ACORN displays striking similarities to other cases, it also represents a different trajectory in housing activism that combines direct action with an engagement with party politics as social democracy seeks to return to its roots.
\end{abstract}

Key-words: Housing Activism, Class, Direct Action, Community Union, Social Democracy.

\footnotetext{
${ }^{1}$ (Andrew.Mathers@uwe.ac.uk) Dr. Andrew Mathers is a Senior Lecturer in Sociology \& Criminology. His publications are mainly in the field of labour and social movement studies notably, Mathers (2007) 'Struggling for a Social Europe: Neoliberal Globalization and the Birth of a European Social Movement' (Aldershot, Ashgate) and Upchurch, Taylor \& Mathers (2009) 'The Crisis of Social Democratic Trade Unionism in Western Europe: The Search for Alternatives' (Aldershot: Ashgate).
} 


\section{Resumen}

Los efectos materiales de la austeridad en el Reino Unido (RU) han generado un resurgimiento de iniciativas activistas en la esfera de la vivienda. ACORN, una organizacion federadativa, es una de estas iniciativas que desafia practicas y políticas de vivienda tanto a nivel local como nacional. Tomando a ACORN como ejemplo y punto de partida intento analizar y evaluar prácticas de activismo de la vivienda en el RU partiendo de los más conocidos casos de España y Alemania (Ordóñez y otros, 2015). Para ello utilizo la metodología cualitativa y hago un estudio comparativo del marco de antecedentes ideológicos y sociales, repertorios y lógicas políticas para presentar y analizar el papel desempenado por ACORN. Concluyo que aunque ACORN tiene semejanzas notables a otros casos, representa una trayectoría diferente en el activismo de vivienda que mezcla la acción directa con una participación con ideologias de partido mientras la democracia social que intenta volver a sus raíces.

Palabras-clave: Activismo de vivienda, clase, acción directa, unión comunitaria, democracia social.

Writing in Araucaria, Ordóñez et al (2015) used case studies of organisations leading housing activism in Spain: La Plataforma de Afectados por la Hipoteca (PAH) and Germany: Bündnis Zwangsräumung Verhindern (BZV) to suggest that citizen activism contesting the outcomes of austerity politics may be producing a general pattern whereby traditional forms of social democratic organisation and mobilisation are being increasingly displaced by direct action. This activism, they argued, was characterised by a largely leaderless form of organisation with a prime focus on the material situation of citizens suffering under austerity policies whose activists therefore favoured a pragmatic rather than ideologically rigid form of politics. The conclusion to this article recommended further investigation of this phenomenon and listed organisations across various European states (Italy, Greece, Turkey, and France) that were operating in the field of housing activism. It is unsurprising that the UK was absent from this list as housing activism in the first decade of the twenty-first century was restricted largely to defensive struggles to hinder the privatisation of existing public housing provision (Glynn, 2009). However, inspired by a sister organisation in the USA, in 2014 a new organisation, ACORN, entered the field. ACORN now has over 600 members in Bristol alone with a list of 2500 email contacts and an impressive social media following that generates a significant mobilisation capacity that has attracted significant mainstream media interest both locally and nationally. From its base in Bristol, ACORN has branched out to form a federated organisation 
across various towns and cities which increasingly contests national, as well as local, housing policies and practices, meaning that it has not only stopped tenants being evicted by collective direct action, but has also contributed to a successful national campaign resulting in changes in legislation relating to security of tenancy and thereby stopping "no fault" evictions.

This article uses the case of ACORN to answer the call for further investigation of housing activism in Europe and to extend the analysis to the UK. In particular, it explores the extent to which "a more general pattern is emerging" and whether the "displacement of a traditional social democratic agenda by direct action is being replicated" in the UK (Ordóñez et al., 2015: 150). This article therefore follows the same analytical structure as its precedent and examines the social and ideological backgrounds of the activists, the political repertoire adopted by the organisation, and the political logic that it expresses.

\section{Methodology}

As with the article on housing activism in Spain and Germany, the methodology adopted to examine it in the UK is a case study and in relating ACORN to PAH and BZV it is also a comparative case study. It too utilises a range of qualitative methods including in-depth interviews and analysis of websites and Facebook pages. It also uses journalistic materials that encompass mainstream news sources such as national newspapers like The Guardian and local newspapers like The Bristol Post as well as independent newspapers such as the collectively owned and co-operatively run The Bristol Cable. All of the interviews were conducted with members of branches in Bristol which have over 600 subscription paying members. Access was gained initially by contacting the paid organisers who sought authorisation from elected national officers to approach members for interview. This enabled the first interviews to be with the paid organisers and subsequent activists were recruited through "snowball sampling" (Handcock \& Gile, 2011). Ten interviews were conducted with a blend of paid organisers, elected officers and activists. The interviews were largely unstructured, although some similar trigger questions were utilised in order to elicit answers that were pertinent to each of the three elements of the investigation. Interviews ranged in length from 50 minutes to 1 hour 30 minutes. Due partly to previous research conducted with social movement organisations in which activists wished strongly to be identified in published outputs it was decided to attribute quotations, but to offer those interviewed the opportunity for non-identification or to withdraw certain extracts of the data. I have been present as a citizen at several protest events organised by 
ACORN and this will, inevitably, have contributed to my understanding of it. As participant observation did not form part of the methodology, no data was collected at these events.

\section{ACORN: the context}

The financial crisis of 2008 discredited the incumbent Labour government resulting in 2010 in the election of a coalition government of the Conservative and Liberal Democratic parties that implemented a robust austerity politics of spending cuts to public sector incomes and services and accelerated the marketisation and privatisation of public services that had proceeded under successive Labour administrations. Austerity generated significant, but limited, resistance from social movements. Unions were slow to mobilise and strike action was largely limited to one-day protests. This was characterised as a situation in which "the legitimate grievances of working class communities" were largely unrepresented resulting in "a vacuum in which effective political representation does not exist" (White, 2016: 19). This space was filled partly by student protest over the tripling of tuition fees (Ibrahim, 2011) that was marked by an occupation of Conservative Party headquarters and culminated in an attempt to storm Parliament. Student protests fed directly into direct actions organised by UK Uncut (Little \& Grayson, 2012) which highlighted rising inequalities and alternatives to austerity, but this remained marginalised and consensus over the necessity of austerity reigned in the public and political spheres and this was expressed by the re-election of Conservative Party to office in 2015 as the sole governing party. It was re-elected in 2017 as a minority government and in 2019 with a large majority.

The age of austerity has seen housing become a major national public issue. This was highlighted by the fire in Grenfell Tower that symbolised the rundown of social housing resulting from its privatisation through the "right to buy" scheme, the proceeds from which local councils were prohibited from using for house construction. Unlike in Spain, where mortgage default was endemic, mass defaults were avoided initially by the state rescue of banks and building societies with exposure to the sub-prime mortgage market and then by a prolonged period of extremely low interest rates and other schemes to support home ownership (Hodkinson et al, 2012). Owner occupation has however stalled as house prices have continued to rise significantly, fuelled partly by an influx of capital into property manifested, most noticeably, by the remarkable expansion of the "buy-to-let" market which in the UK is dominated by small-scale landlords (Beswick et al, 2016), and the concomitant growth of letting agencies acting as intermediaries. This process has been experienced mainly as rising rents 
and worsening conditions amidst lax regulation that promotes the short-term tenancies that generate housing insecurity and its associated psycho-social harms (Bone, 2014). The experience of London (Glucksberg, 2016; Elmer \& Dening, 2016) exemplifies this process, but it is also rampant in Bristol where the private rental sector has grown rapidly and has formed ACORN's main focus.

\title{
Social and Ideological Background
}

Like their counterparts in Spain (PAH) and Germany (BZV), the social composition of ACORN is varied, ranging from lower paid workers, through migrants and onto students. This is a reflection of the diverse population of Easton, Bristol from where ACORN emerged and the other largely metropolitan cities to which it has spread. In Bristol, ACORN's membership includes people living in all forms of housing tenure, yet its mainstay is amongst younger people, aged mainly from their early twenties to late thirties, living in the private rented sector many of whom would previously have moved onto home ownership, but are now priced out of this tenure. This situation is shared by many of its activists and paid workers who, through the relative longevity of their situation and their largely negative experiences of living in this sector, have come to associate themselves with the identity of "renter". District Branch Chair, Jack Windle, recalled how

\begin{abstract}
we were paying an exorbitant rent, a huge proportion of my income was going over to them - and yet despite that we were being made to feel like we were not looking after the property. That we were in some way wrong. And there was just the kind of background sense of anxiety, and resentment and yet powerlessness. ... You go along to meetings and you are trading stories about how you are being fucked over by landlords basically. ... it definitely, it sets up an 'us and them'.... It is kind of about forming that identity (renter) and using it to have some power in that relationship.
\end{abstract}

This emerging identity has been seized upon by ACORN as a means of addressing the "atomised nomadism" (Bone, 2014) produced by the rapid turnover of the private rented sector in order to promote ongoing solidarity and mobilisation, but it has also been an outcome of its activity. An important step was adopting the hashtag, \#rentersrising, which expresses a rejection of rising rents in favour of an uprising of renters. National organiser, Nick Ballard, asserts that

Our existence is our biggest win and the creation of renters as an identity. It didn't exist before. ... In recent memory renters haven't viewed ourselves as a 
constituency with common characteristics, a common cause and all of that. And that's what we've been engaged in building that and that's definitely the biggest success that we have had, building that.

Being a "renter" is not however promoted as a hard, exclusive identity that defines the organisation as ACORN seeks to mobilise support beyond private renters and is keen to move beyond housing issues to other community concerns such as public transport. Housing has remained nevertheless the main and overriding concern of its members and the focal point of ACORN's campaigning.

Ordóñez et al (2015: 141) identified three shared elements amongst housing activist organisations in Spain and Germany: "1) disaffection with political institutions, elections and traditional politics; 2) disappointment with social democratic parties; and 3) a preference for a non-ideological, pragmatic and immediate form of activism". Examining each of these elements in turn indicates that ACORN is strikingly similar, but that there are also interesting inflections that make it a distinctive case. In relation to political disaffection, it is notable that for many activists little or no affection for established forms of politics existed in the first place. Some of the leading activists shared an activist history and trajectory that was impressed by the spectacular forms of nonviolent direct action that were prevalent in the 1990s around the environment in particular, but also linked to housing through a focus on opposing roadbuilding (Wall, 1999). They also participated in the anti-capitalist movement of the early 2000s whose main focus was the summit meetings of global institutions. Many activists in this movement were influenced by the call to "Give up Activism" (Anonymous, 1999; Chatterton, 2006) in the sense of its focus on a small, ideologically motivated group separated largely from a mass base and instead to turn back to grass roots organising that was situated in localities and sought to mobilise mass direct action around everyday material issues. The initial organisers had been involved in trade union activism and attempted unsuccessfully to set up a new trade union that was communitybased. This affinity with trade unionism was reflected in ACORN with its depiction as a "community union".

ACORN was, in part, the product of the widespread distrust and lack of affection for established institutional politics amongst young people particularly and its displacement by nonviolent direct action that had been building from the late 1980s onwards as a key element of the "Do-it-Yourself" (DiY) culture that was spawned by "Thatcherism" (McKay, 1998). However, under the influence of ideas emanating from syndicalist thought and trade union activity, this existing politicised counter-culture was inflected towards everyday material politics and an attempt made to give it a more solid organisational form. The influence of anti-capitalist activism also took this politicised counter- 
culture beyond the postmodern tribalism (Maffesoli, 1996) of the single-issue and identity politics prevalent in the 1990s towards the idea of a broad antisystemic left-wing social movement that cannot be expressed or captured by a single political organisation. Branch organiser, Anny Cullen, explains that

It's part of ACORN's ideology that if you want something done you've got to do it yourself and that we cannot wait for politicians to do it for us. And actually throughout history they have never just done anything for us. And we've always had to organise and to push and put pressure on them to get reforms that we want. ... We are part of like a broader left-wing movement. ... For me being left-wing is all about like the activity that you do to unite people for like our own common interests. ... For me it is more like being totally dissatisfied with the way that the country and the world is run.

That a culture of direct action politics developed from the 1980s onwards is linked to the success of "Thatcherism" in reshaping oppositional politics. The defeat of militant trade unionism in the 1980s was epitomised by the year-long miners' strike of 1984-5 and thereafter the trade union movement largely embraced the ideology of "new realism" that eventually resulted in a strategy of social partnership with employers. Unions also continued to support and fund the Labour Party even as it ended its flirtation with the "New Left" to become "New Labour" (Panitch \& Leys, 1997). The shift from "Bennism" to "Blairism" amounted to a rejection of the market-taming policies of traditional social democracy and an embrace of market-enabling policies. After the financial crash of 2008, the Labour Government bailed-out financial institutions and then sought to reduce the public debt by austerity policies that it continued to advocate, albeit in a softer version, when they were implemented by the Coalition Government of 2010-15. In this political context, many ACORN activists either did not vote or voted for other progressive parties such as the Green Party which rejected austerity politics. Jack Windle recalls that despite being from a family steeped in the traditions of the trade union and labour movement, he felt "disenfranchised ... and alienated from politics". This was confirmed by ACORN National Board member, Jane McDowell, who suggested that "I never voted for Blair ... Labour were Conservative-lite. I could not understand why any traditional Labour voter would have voted them". She also expressed her disillusionment with mainstream trade unionism as well which has failed to act effectively to oppose austerity politics and its material outcomes. She stated that "I do believe in the power of unions and I am somewhat disappointed with a lot of trade unions at the moment because they don't seem to be using their power to do any good".

This disappointment and disillusion with social democratic organisations and politics altered rapidly after the unexpected election in 2015 of Jeremy 
Corbyn to the leadership of the Labour Party. Described as "one of the last standing Bennites in the Labour Party" (Seymour, 2016: 3), Corbyn's consistent support for progressive causes such as anti-apartheid, lesbian and gay rights and peace movements is combined with a background in the trade union movement. His leadership, therefore, is symbolic of a profound shift to the Left in the Labour Party away from "New Labour", arguably back towards "Old Labour". Most significantly this has been expressed as an outright rejection of austerity politics and a commitment to the welfare state. This political shift has resonated with many ACORN activists who saw in Labour's 2017 General Election manifesto a commitment to policies and programmes that chimed with their own demands such as rent control and a mass social housing building programme. This attracted the support of hitherto sceptical activists. Jack Windle not only began to vote for Labour, but joined the Labour Party. Jon Hardy, District Branch Secretary, recalled his journey away from "anti-party politics" and how he was "ecstatic" when Corbyn was elected leader and joined the Labour Party and Jane McDowell voted Labour for the first time in 2017. She explains her changed view in terms of what a Labour government could do in relation to housing, "I definitely view Labour differently. ... looking back at history ... all of the social housing that was built just after the war, to my mind that was a brilliant government. ... It would be great to have a government like that again". In general, some of the older, more seasoned, activists joined the Labour Party pragmatically to vote for Corbyn as leader whereas the younger, less experienced, have tended to invest more belief in his project to turn the Labour Party towards a democratic socialist orientation, albeit currently with policies more akin to traditional social democracy.

Interviews conducted with activists revealed a keen understanding of the policies and underlying systemic causes of the housing crisis. At an abstract level, there was a general consensus that housing has become a commodity whereas it should be a fundamental human right. At a concrete level, the situation of renters in the private sector was linked back explicitly to a longstanding political attack on social housing by successive governments as part of a general assault on socialised assets and the welfare state. This was combined with more recently devised austerity related policies that restricted central and local government spending in the fields of housing and associated welfare benefits. These policies were overlain by the promotion of a culture of viewing housing as a property investment rather than as a home for people. This culture has fuelled rising house prices which, combined with a decline of social housing, has been compelling increasing numbers of people into the private rental sector where they have been experiencing a range of everyday issues and problems. This linkage between addressing immediate material problems and underlying systemic causes is expressed clearly by Anny Cullen, 
There are nine times as many homeless people on the streets as there were five years ago ... and I struggle to make my rent every month, so that's where we have got to be fighting ... and like this is all coming out of an economic setup that is doomed to fail. It's just protecting people at the top at our expense. Personally, and a lot of ACORN members agree, we're not willing to keep paying for it anymore.

This discourse of social division is prevalent amongst ACORN activists and is largely expressed in class terms. Activists tend to profess a pride in being working class alongside a clear sense of 'us' and 'them' with renters and large landlords exemplifying each of these classed categories. Branch Membership Officer, Ajmal Miah, asserts that

landlords are organised as a class and they are getting their way ... and it's about time we got organised as well ... I would say that class is the issue that ACORN organises around because tenants, it's a class-related issue - and tenants are usually working class people.

Despite its understanding of the underlying causes of the housing crisis, ACORN's main focus on addressing the everyday manifestations of it means that, as an organisation, it is certainly aligned with the non-ideological, pragmatic and action-oriented politics of housing organisations in other European states. This is a politics that is primarily about producing results on the ground. Nick Ballard emphasises how the approach of ACORN is to be "ideologically pragmatic ... because it is about the outcomes and not having a particular set of beliefs". This is put succinctly by local Branch Secretary, Esme Roslin, who states that "I'm in favour of it (direct action) because it works". Although ACORN certainly shares the ideologically pragmatic outlook seen in the other cases, there is a clear viewpoint amongst many of its leading activists that everyday mobilisation around housing issues is framed by, and linked to, a broader project of social transformation. This is expressed most prominently in the slogans that appear on ACORN's leaflets, web pages and the t-shirts worn by activists during mobilisations. Its initial slogan, 'everything for everyone' connotes a goal that is akin to the abolition of private property. This slogan was replaced in 2017 with 'taking what's ours' that suggests a project of common ownership through acts of re-appropriation. Jack Windle explains this by saying that "people have taken our shit and we want it back ... things like all the soldoff council (social) housing". The way that ACORN addresses, and attempts to link together, the three levels of housing activism (everyday problems; singleissue campaigning; systemic change) identified by Glynn (2009) can be seen in its political repertoire. 


\section{Political repertoire}

As with the cases of PAH and BZV, the political repertoire of ACORN is highly plural and it also shares the same two premises: protest is non-violent and it displays a penchant for experimentation regarding the political tools deployed. This willingness to experiment has enabled ACORN to complement its mainstay of confrontational direct action with forms of institutional action that operate within existing political structures of government and political parties. The embrace of experimentation has been driven largely by the desire to move beyond forms of action that while expressing resistance may be largely ineffective, towards action forms that are successful in achieving concrete goals. In other words, “winning” plays a pivotal role in ACORN's political repertoire.

Like its Spanish and German counterparts, blockading evictions has been an important element of ACORN's repertoire. However, unlike in Spain where hundreds of activists have been mobilised, the relatively smaller numbers seem to be oriented partly towards physically preventing the eviction, but mainly towards bringing it to public attention thereby mobilising power through public shaming. This is vividly and aptly depicted by Jane McDowell who explains how ACORN are willing "to go and tell the shitty landlord ... what a big shitbag you are". This has worked in relation to cases of unwanted sexual attention by landlords and unmet repairs and undelivered services, with publicity extending even to prominent national media such as the British Broadcasting Corporation (BBC) (Smythe, 2017). This moral pressure has been generated imaginatively such as in the case of a couple whose eviction was due around Christmastime. This was highlighted by activists singing carols (with the words altered) outside the home of the landlord. To the tune of "O little town of Bethlehem", the protestors sang,

O little town of Shirehampton how still we see thee lie, but underneath your pretty streets the landlords bleed us dry ... The oven was not working, yet still they charged them rent. No thought for need, just pure greed, the landlord should repent (ACORN, undatedA).

The efficacy of these direct confrontations lies primarily in status damage to the targeted landlord both in their own eyes and in those of their neighbours. In another case the targeted landlord was a Director of Bristol City Football Club and his standing in the community was damaged through local media coverage that highlighted the alleged illegality of the eviction (Cork, 2018a). This focus on individual landlords reflects the character of the local private rental sector as does the prevalence of letting agents who manage properties for landlords who have neither sufficient time nor the expertise. These agencies 
have also been targeted, but here the damage inflicted is focussed more on how bad publicity and the concomitant reputational damage can harm revenue and profitability. One action against agent, Zed \& Co, was focussed on its alleged failure to display its letting fees the alleged illegality of which was highlighted by surrounding its office by crime scene tape (Cork, 2018b). According to activists, another protest at the offices of "Liv N Let" (Rose, 2015) resulted in extensive repairs to renters' accommodation costing $£ 30,000$ being undertaken. Mobilisation at the offices of this agency again seemed like an attempt to channel moral pressure onto the company owner as well as inflict material damage on the business. A song sheet suggests that demonstrators outside the company offices sang, to the tune of "Wonderwall" by Oasis,

\begin{abstract}
Del Brown, the word around the town is that the houses that you rent are crap. We're sure you've heard it all before but you clearly never gave a damn. Now we know that everybody feels the way we do about you now. Live N Let, the money that you get is the rent that we cannot afford. We know we're paying for your cars and your fancy holidays abroad. You can't hide behind your money, we are here to claim what's ours. ... Because ACORN is gonna be your downfall ... (ACORN, undatedB).
\end{abstract}

Facebook posts and ACORN activists suggest that for certain tenants the threat of involving ACORN or just an email has been enough to resolve certain cases favourably. ACORN has moved beyond highly specific grievances to campaign on issues affecting all tenants. A campaign to highlight the problem of "rogue" landlords was addressed by the successful demand for Bristol City Council (BCC) to adopt an Ethical Lettings Charter (ELC). Demonstrations calling for the abolition of letting fees have occurred in several cities and this matter has since been addressed by legislation (Brignall, 2019).

Actions that directly confront financial institutions, including such banks as Santander, National Westminster, and the Trustees Savings Bank (TSB), have enabled ACORN to connect single-issue housing campaigns to broader socio-economic affairs thereby setting housing matters within a "wider political analysis" (Glynn, 2009: 282). For example, ACORN groups in Bristol, Birmingham, Sheffield and Newcastle protested simultaneously and successfully to alter a clause in the TSB's "buy-to-let" mortgage contracts that prohibited renting to benefit claimants, asylum-seekers and students (Sabbagh, 2018). Protestors took their demonstration inside the bank to highlight how 'the bankers crashed our economic system' and were rescued by the state yet "they are making life a lot harder for tenants" (Cork, 2018c: 5). Other campaigns, targeting private property developers which minimise social housing units in new developments, demonstrate well the diversity of ACORN's action repertoire which spans from confrontational direct actions 
to lobbying local government. As with the banks, the direct actions aim to damage the organisation's reputation and brand in the eyes of the public and public officials through spectacular actions such as disrupting the launch party of an up-market housing development in central Bristol. A bridge constructed across the river to provide access to the "Finzel's Reach" development was blockaded by protestors thereby hampering access to the party for the guests who were "mostly corporate clients, planning chiefs, other developers and construction firms" (Cork, 2017: 6). New developments often bypass local government "affordable" and social housing quotas through secretive viability assessments and so ACORN has pressured BCC successfully to ensure that these assessments are made public (Gilling, 2018). Such campaigning is an expression of how ACORN has largely eschewed expressive forms of direct action such as occupying sites earmarked for development in favour of institutionally focussed actions that politicise an issue and involve greater grass roots participation through petitioning, public meetings and demonstrations. This combination of institutional and extra-institutional forms of action is evident in the relationship between ACORN and BCC.

ACORN's report on housing conditions in the private rental sector that underpinned the case for the ELC was supported formally by two prospective parliamentary candidates for the Labour and Green parties as well as by over 1600 renters (ACORN, 2015). ACORN's focus on devising an ELC brought it into a direct, positive, and productive relationship with BCC. The ELC was endorsed by councillors at a BCC meeting lobbied by over 100 ACORN members and was signed ceremonially by the Mayor at a public meeting held in City Hall, dubbed the "Big Housing Conversation" which enabled tenants and activists to discuss housing matters directly with leading councillors such as Paul Smith, the Cabinet Member for Homes (Aviram, 2015; Ayotte, 2016). Jack Windle recalls how Paul Smith's speech in support of the ELC was delivered while wearing an ACORN t-shirt, yet while Smith welcomes mobilisation by ACORN as evidence of popular support for Labour's progressive housing policies, he remains the target for "friendly pressure". Achieving the ELC was one aim of the 'Bristol Homes Board' set up by BCC as a partnership board with the goal of implementing its housing strategy. Being given a seat on the Board was a recognition by BCC of ACORN as a legitimate voice for tenants (BCC, 2016). Rising to the "top" so quickly and putting a foot in the corridors of local government power are signals of the efficacy of ACORN's experimental repertoire, but this has not restricted its willingness or capacity to protest against $\mathrm{BCC}$, especially relating to austerity-driven policies. One prominent campaign has demonstrated an interlinking of institutional and protest actions that reveals some interpenetration of movement and party activists. 
BCC's proposal to eliminate discounts on Council Tax bills for around 25,000 of Bristol's poorest residents was followed by a consultation process that included three options none of which allowed citizens to voice complete opposition to the proposed reductions. ACORN's campaign to maintain the discounts demonstrates its experimental repertoire and how its anti-austerity agenda is framed in a class discourse. An ACORN activist described the BCC proposal as implementing "Tory austerity" meaning that "the poorest in society have already borne the brunt of ... economic policy to reduce the deficit. But this deficit was not caused by the frivolous spending of working class households, but by the irresponsible gambling of big banks and finance" (Cullum, 2017: 3). ACORN encouraged its members to engage in the BCC consultation process by rejecting all three options and by asserting a fourth option of no reductions. This was supported by petitioning door to door, at street stalls and outside schools thereby generating 4000 signatures, by public meetings, and by social media posts. One short film posted on Facebook had over 6000 views and highlighted the human costs of a policy that was "punishing the poor" by compelling them to use food banks (ACORN, 2017a). Another short film with 4500 views asserted that BCC could save money by cutting executive salaries (ACORN, 2017b). Social media use was accompanied by publicity generated through alternative media outlets as well as on mainstream local radio and television.

While maintaining the threat of using direct action against the use of bailiffs should the policy be implemented, ACORN's repertoire extended to exerting direct political pressure while also mobilising direct political influence within the Labour Party. Posts on Facebook put public pressure on the Labour administration by demanding "Don't allow the (Labour) Mayor to punish low-income Bristolians for Tory policy!" (ACORN, 2017c). ACORN also published a briefing that was sent to all Labour councillors in which it called on them to "put a clear distance between Labour Party actions in power and Conservative Party Policy" and if not "residents will begin to wonder what the point is voting for a Labour administration". The document also highlighted how this local policy was discrepant with the values of the national party under the leadership of Jeremy Corbyn that was "for the many not the few" (ACORN, 2017d: 5-6). Labour councillors were also lobbied directly by ACORN members and especially those who were Labour Party members. Internal party pressure was also mobilised by ward and constituency parties raising the issue and passing resolutions. At least four Labour councillors had expressed their intention of voting against the proposal, with others considering doing so, before it was withdrawn (Cantwell-Corn, 2017). The proposal was also opposed by Momentum Youth (an organisation associated closely with support for Corbyn's leadership). 
ACORN organised a voter registration drive just prior to the 2017 General Election which was considered by activists mainly as a way of maximising the vote for Labour. ACORN has also addressed Labour Party meetings in Bristol, including the Labour Local Campaign Forum. The very close links and overlapping memberships between ACORN and the Labour Party in Bristol have also been a feature of ACORN in Brighton where for "some members ACORN was understood as part of a strategy to develop 'Corbynism from Below"' (Cant, 2018: 3). At the national level, ACORN has met with John Healey, the Shadow Minister for Housing, to discuss housing policy (ACORN, 2019a). ACORN also received an endorsement from the Shadow Prime Minister, Jeremy Corbyn, who noted the success of its "campaigning work" (ACORN, 2019b). This linkage of institutional politics to grass roots movement activities has also been evident in relation to the Green Party. An ACORN campaign in Bristol to support members facing homelessness due to the closure of a women's refuge (Cantwell-Corn, 2019) was supported by Green Party councillors and members some of whom are ACORN members and activists.

\section{Political Logic}

Ordóñez et al (2015) present the question of the organisation of housing activism in PAH and BZV in terms of the contrasting political logics of verticalism and horizontalism (Robinson \& Tormey, 2005; Feenstra, 2015). Based on the model of ideal-typical characteristics developed by Flesher Fominaya (2007), verticalism is associated with the "institutional left" whose orientation to state power generates a hierarchical model of organisation with a patent and powerful leadership. Horizontalism is associated with "autonomous movements", that by seeking social change without taking power, favour participatory and leaderless forms of organisation. The "pragmatic and nonideological form of doing politics" (Ordóñez et al, 2015: 149) favoured by both PAH and BZV resulted in a creative tension of verticalism and horizontalism. A highly similar approach to politics is also evident in the case of ACORN and this has also generated a creative combination of verticalism and horizontalism. However, as a self-styled "community union", it would appear to aspire to be recognised as part of the 'institutional left' in that unions are deemed as a "legitimate political actor" in this model, while also demonstrating elements of "autonomous movements". This is akin to radical unions in Spain which Flesher Fominaya (2007: 346) posits as examples of "social movement groups with features of both models". ACORN does indeed display elements of a membership-based, representative institution with a formal structure and 
a discernible leadership while also practising a social movement style of participatory and inclusive democracy.

ACORN's approach to organising indicates a clear distinction from the political model of the "institutional left" in which participation is "based on political and ideological credentials and membership" (Flesher Fominaya, 2007: 338). There was a common perspective amongst activists that ACORN should eschew an overly ideological approach to organising and that it should maintain formal independence from all political parties. ACORN meetings have tended to be chaired in a way that has enabled political views to be expressed, but the search for a common political viewpoint has been ruled out. In meetings, expressions of abstract ideological positions have been discouraged in favour of contributions focussed on advancing a concrete campaign or a collective action. Activists have operated with an ethos that meetings are "to achieve a goal and not to prove a point" recalled, District Branch Secretary, Matthew Hollingshead. This outlook is summarised by Jack Windle, who suggests that "we are certainly not apolitical (laughs), but we are very much focused on winning ... because it is pragmatic we have a coalition really of people who share the same interests but do not necessarily share the same ideological viewpoint".

Activists have also rejected the purely horizontal approach to organising in which the emphasis is on reaching a consensus amongst the community of radical activists around whom autonomous movements are formed. Jon Hardy, suggested that "I think people had come from these kind of lateral, anarchist ... some people were fed up with nothing ever happening because everyone has to agree with everything all the time or consensus or whatever". ACORN activists have regarded decision-making by consensus as an unproductive way of organising and, while favouring deliberation prior to choosing a course of action, voting is regarded as a necessary and effective resolution to any disagreements. This suggests a non-ideological and highly pragmatic approach to politics which translates into a concern with effective forms of organisation. The emphasis on efficacy is evident in statements from activists who when asked about how ACORN is organised stated that it's "... about getting stuff done" (Anny Cullen), “... (a) triumph of function over form" (Jon Hardy), “... to be effective ... it's definitely all about winning" (Nick Ballard). Matthew Hollingshead likened the organisation to an "organic machine" to process "the fuel (of) working class anger" and emphasised that this approach to organisation was part of seeing politics as "a means to an end". In essence, for ACORN, organisational matters seem to be concerned much less with the optimum use of resources (efficiency) and much more with being successful in producing the intended result of collective mobilisation (efficacy). 
Barker (2001) suggests that a focus on organisational efficiency that places organisational means above the ends of effective collective action has been dominant in the mass, bureaucratic organisations particularly prevalent in the trade union movement dominated by social democratic thought and practice. In such bureaucratic organisations decision-making is centralised and communication flows from above. Hierarchy also engenders mass passivity, low levels of participation, and conservatism due to a focus on organisational maintenance. Barker argues against the idea that the bureaucratism and conservatism of such organisations are an inevitable product of the "iron cage of rationality" (Michels, 1915), but are rather historically contingent outcomes. Barker argues that organisations focussed on mass, collective action could be run more democratically through maximising participation and that this is most likely to occur when there is an impulse generated by mobilisation from below. As mentioned earlier, due mainly to the emergence of housing as a pressing social issue and renters existing as a largely unorganised and unrepresented social group, ACORN has benefited from a significant momentum from below that has brought a rapid increase in members and active participants. The development of housing into a prominent political issue at both local and national levels has generated an impetus for ACORN to rise quickly "to the top". It engages regularly with institutions and institutional leaders through which locally there has been, or regionally or nationally there seems to be, the prospect of tangible gains. These tendencies have resulted in frequent organisational developments as ACORN has attempted to develop in the union tradition with a subscription paying membership which engages through branches that elect officers which form a local, and increasingly national, leadership. In Bristol, where membership grew swiftly, a city-wide branch was restructured in 2018 into several neighbourhood branches in an attempt to maximise its rootedness as a "community union".

In interviews, activists consistently reiterated a very similar narrative of how ACORN branches were created through "digging for local issues" in neighbourhoods. Esme Roslin recalls how for her this was "just like your neighbour knocking on your door". Those affected by these issues were then mobilised to attend public meetings at which grievances were aired and specific housing issues were adopted as the focus for campaigns. Such meetings are akin to the assemblies of BZV and PAH in that they were spaces that enabled the sharing of common experiences and the fostering of solidarities resulting in the shared and empowering identity of renters rising up against exploitative landlords. This is evident in the first quotation from Jack Windle (above). Matthew Hollingshead explained how such meetings helped ACORN in that it "kind of built the community that it was organising". Public meetings were composed of a diversity of social, occupational and ethnic groups who through 
"saying that the rent it too goddamn high and everyone has got mould" became "just people dealing with each other as people with a shared experience and a shared interest". This formation of new solidarities and identities as the basis for collective action demonstrates how ACORN has not only been about efficacious organisation in the practical terms of 'making new things happen', but also in the symbolic terms of "making new meaning" (Fantasia \& Voss, 2004: 107).

As with PAH and BZV, ACORN activists have been concerned with practising "a democratic and inclusive style of politics" (Ordóñez et al, 2015: 147) and so the voice and vitality displayed in public meetings has been, to a significant degree, translated into the everyday branch life of ACORN. Several activists highlighted the inclusive culture of meetings that minimised the obstacles to participation and were conducted so as to ensure maximum participation. For example, branch meetings in Bristol minimised the information giving element and formed small working groups in order to maximise the spaces and time available for a deliberative process through which campaigning issues were identified and prioritised. Reflecting on such meetings, Ajmal Miah suggests that

\begin{abstract}
Without it being forced, it's somehow like everyone gets involved. ... ACORN meetings are (pause) I am trying to find the opposite word of daunting ... It's really welcoming. .. You go to meetings of like left-wing groups and there's like jargon being thrown like left, right and centre and you know you have got like no idea of what's going on. ACORN is not like that. It is a lot more inclusive in a way. ... It's about actually talking about issues and working things out ... If the system is opened for you to actually have your say in it then you feel a sense of responsibility and that's how you feel that stake in the union.
\end{abstract}

Or as Jack Windle puts it straightforwardly, in meetings "they (members) don't just fucking sit there and listen to other people talking. They have to do some stuff and they leave like feeling energised and enthused to get involved". Once the deliberative process has run its course, campaigning decisions are taken by majority vote and each branch has some autonomy in how to conduct the campaigns and the associated direct actions. This has enabled some spontaneity and, with minimal barriers to participation, it has on certain occasions enabled a voice for the most affected and marginalised members of society. ACORN member, Patrick Graham, recalls how a young, homeless passer-by joined an ACORN demonstration outside the TSB and within a few minutes was addressing the crowd. At another demonstration outside a business-owned by a local landlord, the involvement of by-standers added to a confrontational and confused atmosphere. This was later dissected and debated by participants as well as by the local leadership group that is comprised of branch officers. 
ACORN is, unequivocally and unapologetically, a vertically structured organisation. It has a formal structure in which paying members join branches which are federated together within and across cities. It has an annual conference made up of elected delegates which makes strategic decisions, a National Board for affairs of governance and a National Strategy Group for addressing pressing campaigning issues. Subscriptions are also levied in order to employ paid organisers the turnover of which is quite high. Although branch officers are elected, in Bristol a culture of turn-taking has developed resulting in the frequent rotation of officer positions and a high rate of renewal. On a day to day basis, the leadership team operates quite autonomously and is in almost constant contact via social media. Although activists spoke of the aim to make officers as responsible and as accountable as possible, there was a recognition that the main purpose of organisation was effective mobilisation. Jon Hardy explains how "of the 5070 people who I know in ACORN ... it's the understanding that it's not slow and perfect democracy, in terms of not everyone's involved in everything ... (pause) you gotta get things done. Which I think is the fundamental thing". It is evident in ACORN that pragmatism trumps purity in relation to organisation and that democratic functioning, although desired and aimed for, translates in practice into democratic sufficiency in the sense of maintaining member and activist engagement while maximising mobilisation. ACORN nonetheless attempts to develop the capacities of its members and engages in leadership development. Esme Roslin explains how "we want to kind of nurture the people that we have to allow them to grow so that they can start to lead things as well". This is achieved partly through delivering training programmes for would be organisers. Jack Windle asserts that

\begin{abstract}
"we are very genuine about getting people and not fucking leading them but turning them into leaders ... Skilling people up and empowering people to be leaders themselves means that there is not this weird 'saviour' thing .... and to me that's the most amazing thing about ACORN. ... People who come along and join because they are angry ... and actually over a couple of years you will see them really grow in confidence and really become kind of quite mature as activists and really start to get the politics and be able to convince other people".
\end{abstract}

This approach to developing the strategic capacity and resourcefulness of the organisation is reminiscent of the enabling form of leadership found in democratic organisations as opposed to the disabling form of leadership characteristic of bureaucratic organisations (Barker et al, 2001). 
This enabling aspect is highlighted by ACORN's representative on Bristol City Council's Homes Board, Tom Renhard, who suggests that leadership in ACORN "is not about someone being really gobby or a real force of personality, it is about can they bring people with them. Are they able to campaign on something, get people to mobilise, get people to take on roles so that they are not taking it all on themselves"? This has produced a situation which is summarised by Ajmal Miah as one in which "... in the context of ACORN a leader is someone who brings out the best out of everyone else ... (so) there are a lot of leaders, but nobody is fighting for dominance". Many activists highlighted the notion of how ACORN operates according to "sweat equity" meaning that "if you do the work, then you do get a lot more respect from people, and naturally you are going to be the person that is like voted for to be one of the leaders" (Anny Cullen). This means that leadership legitimacy tends to be based neither on charismatic authority nor on the legal-rational authority derived from election to official positions as is the case in bureaucratic organisations.

While ACORN is different to BZV in not displaying charismatic leadership, it does display some similarity with $\mathrm{PAH}$ in terms of how positional leadership is eschewed in favour of exemplary leadership which is the capacity to express key issues in "direct and emotive terms" (Ordóñez et al, 2015: 148). However, unlike PAH, ACORN is at pains not to develop any specific public figures who can be spokesperson for the media. Jane McDowell explains how "ACORN is everyone. So there should be a lot of faces and voices and not one figurehead ... and we prefer it if the person speaking is actually having to deal with one of those issues. ... We are not here to advocate for people. We are the people". While not limiting leadership roles to renters, most elected leaders and paid organisers are younger people who are facing, or have faced, the issues on which ACORN campaigns. This emphasis on the authenticity and ordinariness of leaders in ACORN can be viewed as an attempt to eliminate or minimise the social distance between leaders and grass roots members that usually develops in bureaucratic union organisations (Barker, 2001). When asked about leadership, Matthew Hollingshead explained that "... the leaders are the activists, so the sweat equity thing, ... if we are going to scale, we are going to have to start to look for ... the dinner lady who knows everyone and the matriarchs of big families in ethnic communities ... they are the way into a network". This suggests that ACORN aspires to develop the kind of community-based "organic" leadership (McAlevey, 2015) that might realise its ambition to become an organisation with a truly mass membership and mobilisation capacity. 


\section{Conclusions}

As was concluded in the cases of BZV and PAH, ACORN has been largely successful in "developing a non-doctrinal, pragmatic and engaging style of activism with the purpose of struggling for a basic material need: housing" (Ordóñez et al, 2015: 150). This "street politics" has mobilised in significant numbers those most affected by the issues associated with the housing insecurity generated by marketisation and by austerity politics that have hampered the development of an effective social housing sector that could mitigate it. ACORN mobilised mainly renters who had hitherto remained an almost entirely unrepresented social group. This places ACORN alongside other newly emergent organisations in the UK which have successfully mobilised unrepresented groups of insecurely workers such as couriers and cleaners (Roberts, 2018). It is possible therefore to comprehend ACORN's focus on direct action in relation to a broader crisis of social democratic forms of interest representation, the most visible and significant form of which is the crisis of a largely bureaucratised social democratic trade unionism (Upchurch et al, 2009). In its organisation of direct action to address immediate housing needs, ACORN displays two significant characteristics of union renewal in neoliberal times (Camfield, 2007): that organisations can deliver change in the sphere of everyday life (therefore the importance of "winning"), and that those mobilised view organisations as belonging to them and therefore as their responsibility (hence the emphasis on participation and the development of "ordinary" people as grass roots leaders).

As was concluded in relation to BZV and PAH, the emergence in 2014 of ACORN and the rapid growth of its street politics can be comprehended partly through "disaffection ... especially with social-democratic parties" (Ordóñez et al, 2015: 150) and especially due to the Labour Party's acceptance of the discourse and practice of austerity politics. However, as the protest cycle turned, the anti-austerity movement found a political expression in the politics of "Corbynism". In the case of ACORN this was facilitated by a common discourse of class which is part of a shared political culture of the trade union and labour movement. In contrast to concerns raised by White (2016) that social movement protests against austerity could become neutralised by incorporation into political parties, in the case of ACORN it is evident that political party engagement has not displaced street politics, but rather that there has been a realignment of party and movement into a closer (yet still somewhat uneasy) relationship than existed previously. This has generated a new dynamic for mobilisation as new political opportunities have emerged that have held out the prospect for mobilisation to be translated into the institutional power and influence to deliver significant concrete, material gains. At the national 
level this was evident in the commitments to deliver a large social housing building programme and funding for tenants' unions in the Labour Party 2019 General Election manifesto (Labour Party, 2019). These national political opportunities have been closed down by Labour's election defeat but remain largely open in Bristol where Labour is still the governing party and all of the constituencies have Labour Members of Parliament. Bristol does not appear to be an exceptional case as ACORN branches have developed mainly in the larger metropolitan towns and cities, such as Manchester, Birmingham and Leeds, where the Labour Party has continued to enjoy electoral success.

The clear endorsement of ACORN by leading figures in the Labour Party suggests that the environment in the UK of more open political opportunities and a common discourse of anti-austerity that relates material inequalities to class divisions has helped to direct housing activism along a slightly different path to either the cases of Germany or Spain. In Germany, it is possible to conclude that the continued collusion of social democratic and other left parties with austerity (Nachtway, 2009) and their rather authoritarian political culture helps to explain the anti-party politics of housing activism groups such as the BZS. In Spain, the situation is complex and contested. The organisations arising from housing activism, such as PAH, form part of the M-15 movement (Romanos, 2014) that has struggled to maintain mobilisation and to translate societal pressure into policy influence due to political closure (Feenstra, 2015). Activists have therefore provided an impetus to new movement parties against austerity such as Podemos that have sought to incorporate horizontal practices and address pressing social issues (della Porta et al, 2017) and this might help to explain the willingness of PAH to consider engaging in electoral as well as street politics. However, Podemos retains a tension between a charismatic leadership and popular assemblies and reflects grass roots' divisions in that, while displaying a willingness to engage with parties that display horizontal characteristics, activists are keen to maintain movement autonomy from parties (Tormey \& Feenstra, 2015; Flesher Fominaya, 2014). This means that while there are striking similarities between the forms of housing activism in each of these three cases and so a "general pattern" may well be developing, there are also differences that could be explained partly by the different political environments in which they have developed. This suggests that both the general and specific forms of housing activism are being shaped by the trajectories resulting from the decomposition and recomposition of social democratic politics and organisation in the age of austerity. The case of ACORN suggests that in the UK, when faced with austerity and its consequences, citizens have not been restricted to a choice between apathetic disengagement and direct action, but have also had the opportunity of combining direct action with a reengagement with party politics as social democracy has been seeking to return to its roots. 


\section{References:}

ACORN (2015) The Bristol Ethical Lettings Charter: From the houses we have to the homes we need. Retrieved from: https://d3n8a8pro7vhmx.cloudfront. net/acornbristol/pages/273/attachments/original/1440277088/Bristol Ethical Lettings Charter Final _ Email Version.pdf?1440277088

ACORN (2017a) Keep Council Tax Reduction in Bristol!. Retrieved from: https://www.facebook.com/acorn.bristol/videos/1592110967485813/

ACORN (2017b) Keep Council Tax Reduction. Retrieved from: https://www. facebook.com/acorn.bristol/videos/1579821735381403/

ACORN (2017c) Posting on Facebook (18/09/2017) Retrieved from: https:// www.facebook.com/acorn.bristol/

ACORN (2017d) Council Tax Reduction Scheme - Information for Labour Councillors. Retrieved from: https://drive.google.com/ file/d/0B56mYc0PRxW1bXkxT1FDdFpyUVU/view

ACORN (2019a) Posting on Facebook (29/11/2019) Retrieved from: https:// www.facebook.com/acorntheunion/posts/2816520521742312

ACORN (2019b) Jeremy Corbyn's surprising message ... Retrieved from: https://www.facebook.com/acorntheunion/videos/744752739253910/

ACORN (Undateda) Songsheet. Unpublished document. Copy available from the author on request.

ACORN (Undatedb) Songsheet. Unpublished document. Copy available from the author on request.

Anonymous (1999). Give up activism. Do or Die, 9,160-166.

Aviram, A. (2015) A step forward for tenants' rights? Retrieved from: https:// thebristolcable.org/2015/03/a-step-forward-for-tenants-rights/

Ayotte, D. (2016) A Big Housing Conversation to address a big housing crisis. Retrieved from: https://thebristolcable.org/2016/09/a-big-housingconversation-to-address-a-big-housing-crisis

Barker, C. (2001). Robert Michels and the 'cruel game'. In: C. Barker, A. Johnson, \& M. Lavalette (eds.) Leadership and social movements (pp. 2443). Manchester: Manchester University Press.

Barker, C., Johnson, A. \& Lavalette, M. (2001). Leadership matters: an introduction. In: C. Barker et al (eds.) op cit (pp. 1-23).

Beswick, J., Alexandri, G., Byrne, M. Vives-Miró, S., Fields, D., Hodkinson, S. \& Janoschka, M. (2016). Speculating on London's housing future. City, 20, 2, 321-341.

Bone, J. (2014). Neoliberal Nomads: Housing Insecurity and the Revival of Private Renting in the UK. Sociological Research Online, 19, 4, 1-14. 
Brignall, M. (2019). Rip-off letting fees are finally banned - what will happen now? Retrieved from: https://www.theguardian.com/money/2019/jun/01/ rip-off-letting-fees-are-finally-banned-what-will-happen-now

Bristol City Council (BCC) (2016). ACORN join Bristol Homes Board. Retrieved from: http://news.bristol.gov.uk/acorn_join bristol homes board

Camfield, D. (2007). Renewal in Canadian Public Sector Union. Relations Industrielles, 62, 2, 282-301.

Cant, C. (2018). Taking What's Ours: an ACORN inquiry. Retrieved from: https://notesfrombelow.org/article/taking-whats-ours-an-acorn-inquiry

Cantwell-Corn, A. (2017). Pressure builds on mayor to drop council tax changes that hit poor hardest. Retrieved from: https://thebristolcable.org/2017/10/ pressure-builds-mayor-drop-council-tax-changes-hit-poorest/

Cantwell-Corn, A. (2019). How two survivors of abuse were failed. And how they fought back. Retrieved from: https:/thebristolcable.org/2019/02/ how-two-women-were-failed-and-how-they-fought-back-acorndomestic-abuse-housing/

Chatterton, P. (2006). "Give up Activism" and Change the World in Unknown Ways: Or, Learning to Walk with Others on Uncommon Ground. Antipode, 38, 2, 259-281.

Cork, T. (2017). Watch: Dramatic moment housing crisis protestors storm new Finzel's Reach bridge and stop launch party. Retrieved from: https://www. bristolpost.co.uk/news/bristol-news/watch-dramatic-moment-housingcrisis-19552

Cork, T. (2018a). Tears and anger as campaigners stop mum-of-three being evicted from her home. Retrieved from: https://www.bristolpost.co.uk/ news/bristol-news/tears-anger-campaigners-stop-mum-1450851

Cork, T. (2018b). Why a Bristol lettings agents was 'left looking like a crime scene' in row over fees. Retrieved from: https://www.bristolpost.co.uk/ news/bristol-news/bristol-lettings-agents-left-looking-1710818

Cork, T. (2018c). The moment a huge group of protestors stormed a Bristol bank. Retrieved from: https://www.bristolpost.co.uk/news/bristol-news/ moment-huge-group-protesters-stormed-1587667

Cullum, A. (2017). Opinion: We need to fight council tax plans that hit poorest hardest. Retrieved from: https://thebristolcable.org/2017/09/opinionneed-fight-council-tax-plans-hit-poorest-hardest/

Della Porta, D., Fernández, J., Kouki, H. \& Mosca, L. (2017). Movement Parties against Austerity. Cambridge \& Malden (MA): Polity.

Elmer, S. \& Dening, G. (2016). The London clearances. City, 20, 2, 271-277.

Fantasia, R. \& Voss, K. (2004). Hard Work: Remaking the American Labor Movement. Berkeley \& LA (Cal): University of California Press. 
Feenstra, R. A. (2015). Activist and Citizen Political Repertoire in Spain: A Reflection Based on Civil Society Theory and Different Logics of Political Participation. Journal of Civil Society, 11, 3, 242-258.

Flesher Fominaya, C. (2007). Autonomous Movements and the Institutional Left: Two Approaches in Tension in Madrid's Anti-globalization Network. South European Society and Politics, 12, 3, 335-358.

Flesher Fominaya, C. (2014). "Spain is Different": Podemos and 15-M. Retrieved from: https://www.opendemocracy.net/en/can-europe-make-it/ spain-is-different-podemos-and-15m/

Gilling, J. (2018). 'We said it wasn't acceptable': how Bristol is standing up to developers. Retrieved from: https:/www.theguardian.com/cities/2018/ mar/07/bristol-housing-developers-affordable-property

Glucksberg, L. (2016). A view from the top. City, 20, 2, 238-255.

Glynn, S. (2009). Fighting Back: Lessons from 100 Years of Housing Campaigns. In: S. Glynn (ed.) Where the Other Half Lives: Lower Income Housing in a Neoliberal World. (pp. 281-319). London: Pluto Press.

Handcock, M. S. \& Gile, K. J. (2011). 'Comment: On the Concept of Snowball Sampling'. Sociological Methodology, 41, 1, 367-371.

Hodkinson, S., Watt, P. \& Mooney, G. (2012). Introduction: Neoliberal housing policy - time for a critical re-appraisal. Critical Social Policy 33, 1, 3-16. Ibrahim, J. (2011). The new toll on higher education and the UK student revolts of 2010-2011. Social Movement Studies, 10, 4, 415-421.

Labour Party, (2019). It's Time for Real Change. The Labour Party Manifesto 2019. Retrieved from: https://labour.org.uk/wp-content/uploads/2019/11/ Real-Change-Labour-Manifesto-2019.pdf

Little, B. \& Grayson, D. (2012). The National in the Network Society: UK Uncut, the English Defence League and the challenge for social democracy. In: H. Meyer \& J. Rutherford (eds.) The Future of European Social Democracy: Building the Good Society. (pp. 177-191). Basingstoke: Palgrave.

McAlevey, J. (2015). The Crisis of New Labor and Alinsky's Legacy: Revisiting the Role of the Organic Grassroots Leaders in Building Powerful Organizations and Movements. Politics \& Society, 43, 3, 415-441.

McKay, G. (1998). Introduction. In G. McKay (ed.) DiY culture: party \& protest in nineties Britain. (pp. 1-53). London: Verso.

Maffesoli, M. (1996). The Time of the Tribes: The Decline of Individualism in Mass Society. London: Sage.

Michels, R. (1915). Political parties: A sociological study of the oligarchical tendencies of modern democracy. New York, NY: Hearst.

Nachtwey, O. (2009). Die Linke and the crisis of class representation. International Socialism. 124 Retrieved from: http://isj.org.uk/die-linkeand-the-crisis-of-class-representation/ 
Ordóñez, V., Feenstra, R. \& Tormey, S. (2015). Citizens against Austerity: a Comparative Reflection on Platforma de Afectados por la Hipoteca (PAH) and Bündnis Zwangsräumung Verhindern (BSV). Araucaria 17, 34, 133154.

Panitch, L. \& Leys, C. (1997). The End of Parliamentary Socialism: From New Left to New Labour. London: Verso.

Roberts, Y. (2018). The tiny union beating the gig economy giants. Retrieved from: https://www.theguardian.com/politics/2018/jul/01/union-beatinggig-economy-giants-iwgb-zero-hours-workers.

Robinson, A. \& Tormey, S. (2005). 'Horizontals', 'Verticals' and the Conflicting Logics of Transformative Politics. In P. Hayden \& C. el-Ojeili (eds.) Confronting Globalization: Humanity, Justice and the Renewal of Politics. (pp. 209-226).

Romanos, E. (2014). Evictions, petitions and escraches: Contentious housing in austerity Spain. Social Movement Studies, 13, 2, 296-302.

Rose, D. (2015) Easton residents protest "damp and dangerous" housing. Retrieved from: https://thebristolcable.org/2015/07/easton-residentsprotest-damp-dangerous-housing/

Sabbagh, D. (2018) Do you live in shoddy housing that costs a fortune? Time to join the renters' union. Retrieved from: https://www.theguardian.com/ society/2018/jun/03/renters-union-shoddy-housing-cost-fortune-acornbristol

Seymour, R. (2016). Corbyn: The Strange Rebirth of Radical Politics. London: Verso.

Smythe, A. (2017). Taking the fight to 'bad' landlords. Retrieved from: https:// www.bbc.co.uk/news/uk-42083142

Tormey, S. \& Feenstra, R. A. (2015). Reinventing the political party in Spain: the case of $15 \mathrm{M}$ and the Spanish mobilisations. Policy Studies 36, 6, 590606.

Wall, D. (1999). Earth First! and the Anti-Roads Movement. London: Routledge. White, G. (2016). Social movements and social policies: political challenges under austerity in the UK. Contention: The Multidisciplinary Journal of Social Protest, 3, 2, 17-32. 
